\title{
Reconstruction and characterization of the surface drainage system functioning during extreme rainfall: the analysis with use of the ALS- LIDAR data-the case study in two small flysch catchments (Outer Carpathian, Poland)
}

\author{
Tomasz Bryndal $^{1}$ (D) Rafał Kroczak ${ }^{1}$
}

Received: 9 March 2018 / Accepted: 4 March 2019 / Published online: 11 March 2019

(c) The Author(s) 2019

\begin{abstract}
A surface drainage system (SDS) controls catchment hydrology and acts as an indicator of geomorphologic processes. In this study, a field-based and GIS-integrated approach enabling reconstruction of a surface drainage system, which operates during heavy rainfall in small flysch catchments, has been proposed. The reconstruction is based on the ALS-LIDAR data. The reconstruction of the SDS gave the opportunity for analysis of the changes between the river system and the SDS operating during heavy rainfalls. Results have revealed that the SDS operating during heavy rainfalls is several times better developed than the river system. The density has increased from c.a. 1.5 to $13.7 \mathrm{~km} \cdot \mathrm{km}^{-2}$. Moreover, the structure of the SDS has changed, what was confirmed by the parameters of the Hortonian type of the analyses. The most significant changes were related to the first- and second-order streams. These streams were, the most frequently, the man-origin incisions and natural-origin incisions/concavities on the hillslopes conditioned by micro-relief. The man-origin sub-system reached up to $35 \%$ of the SDS functioning during heavy rainfalls, whereas the sub-system composed of incisions/concavities conditioned by micro-relief reached up to $24 \%$ of this SDS. Smaller lateral valleys included to the SDS during heavy rainfalls constitute up to $37 \%$ of the SDS. The permanent streams constitute the remaining part of the SDS. Changes in the SDS have the influence on the drainage pattern, hydrological response of a catchment, and intensity of geomorphological processes; therefore, the changes in the SDS and their consequences have been discussed.
\end{abstract}

Keywords Surface drainage system · LIDAR · Heavy rainfall · Geomorphological changes $\cdot$ Mountain terrains $\cdot$ The Carpathians

\section{Introduction}

A surface drainage system (SDS) controls catchment hydrology and acts as an indicator of geologic and geomorphologic processes (e.g., Daniel 1981; Dietrich et al. 1987; Loaugue and VanderKwaak 2002; Croke at al. 2005; Rodriguez-Iturbe et al. 2009; Henkle et al. 2011; Han et al. 2012; Kroczak and Bryndal 2015; Kroczak et al. 2016; Galia at al. 2017). Under temperate climate conditions, when the groundwater aquifer

Tomasz Bryndal

tbryndal@up.krakow.pl

Rafał Kroczak

kroraf@up.krakow.pl

1 Department of Geography, Pedagogical University of Cracow, Podchorążych 2, 30-082 Cracow, Poland is drained, the SDS is composed of the rivers. This system changes during hydro-meteorological events (rainfalls or thaws) when other natural-origin incisions (e.g., lateral valleys, micro-relief incision, etc.) and man-origin incisions (e.g., paved/unpaved roads, ditches, plough furrows, tourist trails, etc.) are incorporated to the system. Many works have focused on natural-origin SDS development or functioning (e.g., Horton 1945; Schumm 1956; Strahler 1957; Kirkby 1980; Rodriges-Iturbe and Escobar 1982; Dietrich et al. 1987; Montgomery and Dietrich 1988; Istanbulluoglu et al. 2002; Rodriguez-Iturbe et al. 2009; Mirus and Loague 2013; Roy and Sahu 2017). In the Carpathians, the density of the valleys, which during heavy rainfalls, constitute the natural-origin part of the SDS, is up to $3.5 \mathrm{~km} . \mathrm{km}^{-2}$ (e.g., Bryndal 2014a, b). However, density of man-origin incisions (roads, ditches, furrows, etc.), which during a heavy 
rainfall may be incorporated to the natural-origin part of the SDS, may be several times higher. For example, in the Carpathian Foothills, the road network density often exceeds $9 \mathrm{~km} \cdot \mathrm{km}^{-2}$ (Kroczak et al. 2016) and the density of plough furrows may reach up to $35 \mathrm{~km} \cdot \mathrm{km}^{-2}$ (Słupik 1976). During heavy rainfall, the natural- and man-origin elements of a drainage system are integrated in the one 'real' surface drainage system. Knowledge about the parameters (the density and the structure) of this SDS is important, because this system determines functioning of a catchment during extreme hydro-meteorological events.

So far, detection and functioning of the 'real' SDS during heavy rainfall have been investigated at the plot or small catchment scale (c.a. 0.5 ha) (e.g., Froehlich and Słupik 1986; Froehlich 1991; Loaugue and VanderKwaak 2002; Wemple et al. 2017). In the literature cited, the flow lines (both natural and man-origin) creating 'real' SDS were usually determined by post-event investigation. The approach in which the flow lines are mapped after a heavy rainfall is not transferable to catchments of several $\mathrm{km}^{2}$ in area due to the scale problem. Therefore, in this study, the authors propose a field-based and GIS-integrated approach, which enable reconstruction of the SDS operating during a heavy rainfall with use of the ALS-LIDAR data. The application of the approach in two small flysch Carpathian catchments gave the opportunity to analyse how the SDS operating during extreme hydro-meteorological conditions (heavy rainfall) differ from the river system which operates in 'normal' condition when the groundwater aquifer is drained. The changes in the SDS and its influence on a catchment functioning have been discussed, in the view of the literature.

\section{The study area}

Two flysch catchments located in the Ciężkowickie Foothills (Outer Carpathians) have been selected for this study (Fig. 1). This selection was the consequence of previous investigations which focused on the overland-flow formation process (Bryndal et al. 2010; Kroczak 2010). In the Zalasówka catchment $\left(9.2 \mathrm{~km}^{2}\right)$, more than $68 \%$ has a slope gradient lower than $10^{\circ}$. The land cover is composed of arable lands (33\%), grasslands (33\%), forest (20\%), and others (14\% - build-up areas, roads etc.) (Fig. 1). The settlement development, resulted in fragmentation of rural areas and consequently, dense road network $\left(7.4 \mathrm{~km} \cdot \mathrm{km}^{-2}\right)$ was developed. This catchment represents the agricultural type of the catchment, typical for the Carpathian Foothills. In the Pożory catchment $\left(7.1 \mathrm{~km}^{2}\right)$, more than $55 \%$ has a slope gradient higher than $10^{\circ}$. Arable lands cover $15 \%$, grasslands $16 \%$, and forest $66 \%$ of the catchment area. Agricultural fields (arable land, grassland) are divided similar to the fields in the Zalasówka catchment; however, forests create one compact complex (Fig. 1). The density of the road network reached $8.4 \mathrm{~km} \cdot \mathrm{km}^{-2}$. The Pożory represents the agricultural-forested type of the Carpathian Foothills catchment.

\section{Materials and methods}

Incorporation of man-origin incisions to the SDS-an integrated field-based and GIS approach.

\section{Creation of the high-resolution DEM}

Incorporation of man-origin incisions operating during heavy rainfall to the SDS requires creation of the DEM (Digital Elevation Model), which enable to reproduce roads, ditches, furrows, etc. The ALS (Airborne Laser Scaling)LIDAR (LIght Detection And Ranging) data, released in recent years, give the opportunity to reproduce the microtopography (e.g., Lidberg et al. 2017; Thomas et al. 2017), and the man-origin incisions may be detected on the DEM. In the European countries, the ALS-LIDAR data were mainly developed in the context of the implementation of the Directive (2007/60/EC), where high-quality DEMs were required for flood risk and flood hazard maps preparations. This type of data was also prepared for Poland as the part of IT System of Country's Protection against extreme hazard (ISOK in Polish, program started in 2014). The density of points (pts) for extra-urban areas is $4-6 \mathrm{pts} \cdot \mathrm{m}^{-2}$ and the vertical errors reached the value up to $0.15 \mathrm{~m}$ (for urban areas the density is higher- 12 to $14 \mathrm{pts} \cdot \mathrm{m}^{-2}$ and vertical error is up to $0.1 \mathrm{~m}$ ). In this study, this LIDAR data were the source data for the DEM creation. Then, man-origin incisions were detected on the DEMs with the resolution: $5 \times 5,2 \times 2,1 \times 1,0.5 \times 0.5 \mathrm{~m}$, and $0.25 \times 0.25 \mathrm{~m}$. The DEM-s with the resolution $1 \times 1 \mathrm{~m}$ and lower did not allow to detect smaller forms (e.g., plough furrows), which operate during heavy rainfall. In turn, the DEMs with the resolution smaller than $0.5 \times 0.5 \mathrm{~m}$, presented the surface terrain, where the microtopography was inadequate to the real conditions. The DEM, with the resolution $0.5 \times 0.5 \mathrm{~m}$, enabled detection of the man-origin incisions which differed in terms of the types and size (e.g., paved/unpaved roads, ditches, furrows, etc.). The DEM with the resolution $0.5 \times 0.5 \mathrm{~m}$, selected in this study, is in the range of the DEM preferable resolutions $(0.5-1.0 \mathrm{~m})$ used for hydrological studies, where the role of the microtopography on the water cycle was analysed (e.g., Lanfranc et al. 2017; Thomas et al. 2017).

\section{Preprocessing of the DEM and its adaptations for hydrological analyses}

The DEM created from LiDAR data is very detailed and reflects 'real' terrain surface. The ALS scanning technique 
Fig. 1 Location of the study area-I. Relief and land cover in the Zalasówka catchment-II.A and Pożory II.B catchments. 1-watershed, 2-arable lands, $3-$ grasslands, 4-forest, 5-build-up areas. Source: authors own elaboration based on SRTM (DEM) and orthophotos data from CODGIK (land use)
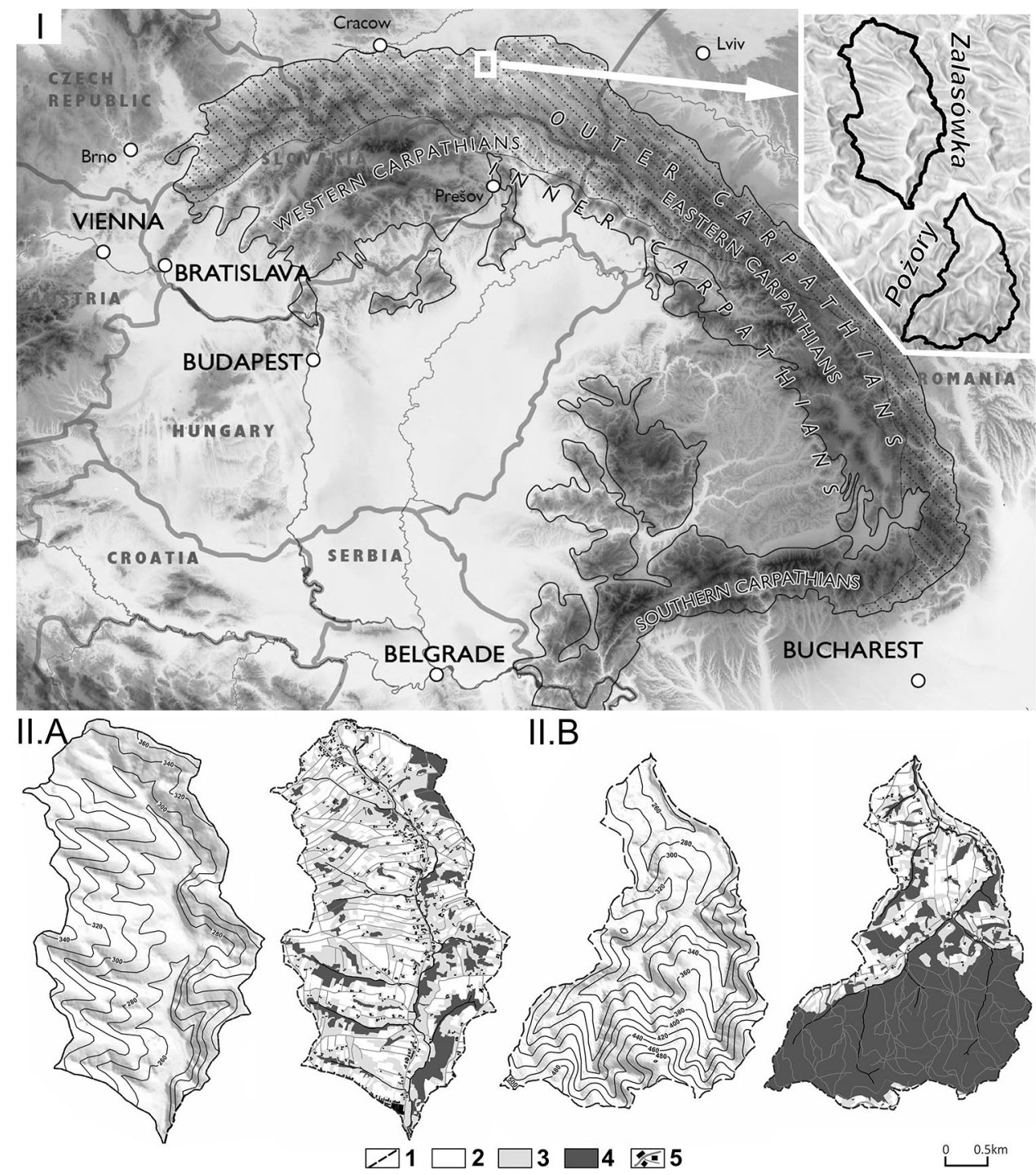

and post-processing of the cloud point allow to 'filtrate' and eliminate larger bridges. However, smaller bridges, culverts, footbridges, etc. (the depth of the channel up to $3 \mathrm{~m}$ ), which normally allow water to flow through them, are reflected as 'artificial dams' which may generate errors for detailed analysis (especially those, related to the structure of the SDS pattern - the case of this study). Use of the DEM, where such 'artificial dams' occur, may generate errors related to the direction of the flow. Consequently, the pattern of the SDS may not reflect the real conditions. For example, small bridge (e.g., c.a. 1-1.5 m high, 5-10 m width) located over the ditch, is reflected as the dam (on the DEM), and prevents the water to flow 'under the bridge' (as it is in real conditions). As a result, the flow may be redirected, e.g., to the parallel ditch, located opposite the road, and the structure of the SDS change. When the 'artificial dams' are not removed from the DEM, the flow lines generated by GIS algorithms may not reflect real conditions of the SDS. Such errors do not influence on large-scale analysis; however, they are not acceptable for detail studies. Therefore, the authors state that artificial dams should be removed. This process is called the optimization of the DEM or stream burning. The assumptions for the stream burning procedure were established in the nineties of the twentieth century (Hellweger and Maidment 1997; Lindsay 2016). The procedure, as universal for raster data, is implemented in the GIS software, and it has been used in this study. Implementation of this procedure for the high-resolution DEM requires very detail input data describing localization and parameters of the 'artificial dams' (bridges, culverts, etc.). The authors recommend following attributes for the artificial dams description: (1) GPS coordinates measured in the centre of bridge/culvert; (2) the width of the bridge/culvert; (3) the depth of the stream/ trench where bridge/culvert was located; and optionally when a stream/trench channel is incised-the depth of channel (Fig. 2, part I). Taking into account precision required 
Fig. 2 The scheme of optimization procedure. Part I-fieldwork measurements (a-localization of the bridge/culverts by GPS coordinates, b-width of the artificial dam, c-depth of form). Part II-the example of the 'burning' of the culvert at the GIS analyses stage alocalization of the digitalized working vector, $b$-width of the artificial dam, c-depth of form. Part III-DEM before and after 'optimization'-the example. Source: authors own elaboration based on ISOK derived ALS-LiDAR data (DEM) and topo map 1: 10,000 from CODGIK
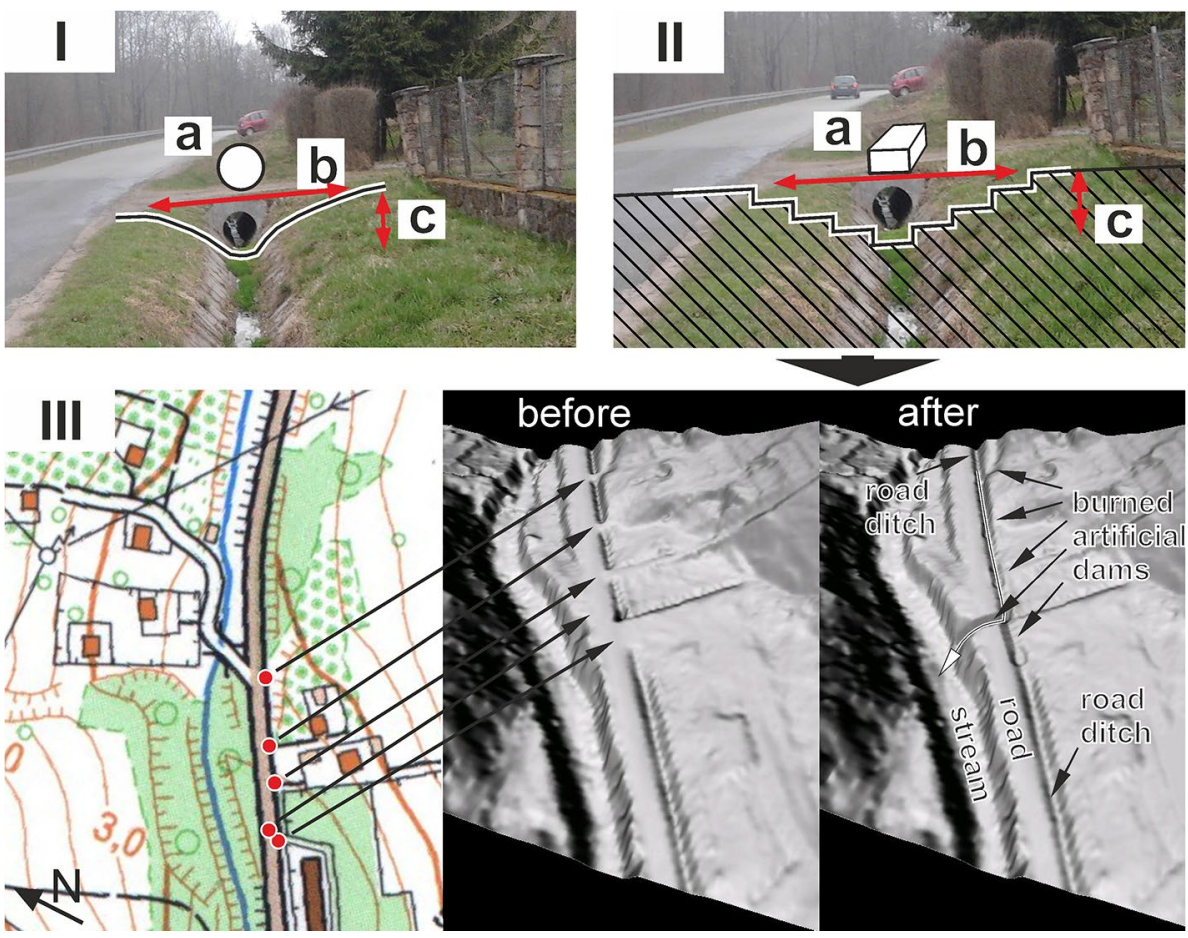

for a high-resolution DEM, these data should be obtained as a result of the field investigation. In this study, 167 artificial dams were identified and described in both catchments and then burned in the GIS software. This process was composed of four steps (Fig. 2):

1. Creation of the point type vector layer, containing the location of 'artificial dams' (on the basis of the GPS coordinates).

2. Digitalization of the axis perpendicular to stream/trench (called working vector-here and after), crossed the points with the location of the artificial dams.

3. Characterization of the working vectors by 3 attributes:

(a) the width - the parameter describes width of bridge/culvert (m),

(b) the depth - the parameter describes the depth (m) of the concave stream/trench form,

(c) the depth of the channel—when a stream/trench channel was incised (it is usually filled by flowing water), the parameter describes the depth of the channel.

Modification of the DEM by burning of the working vector, according to the procedure proposed by Hellweger and Maidment (1997). The algorithm 'gradually burns' (reflected as 'stairs'-Fig. 2, Part II) the artificial dam up to the value described by attribute 'depth-b'. After burning of the artificial dams, the DEM is filtered by fill sinks algorithm. In this way, hydrologically correct DEM is created and the water flow reflects the real conditions (Fig. 2, part III-look at the white arrow).

\section{Models of the catchments contributing to the streams development and delineation of the streams}

The GIS module requires a head channel area parameter to generate the SDS. The head channel areas are usually delineated in geomorphological studies. They are determined: (1) empirically on the basis of field studies; (2) by use of the empirically determined relationship between contributing area and local valley slope at the head channel; or (3) using probabilistic approach (e.g., Kirby 1980; Dietrich et al. 1987; Montgomery and Dietrich 1988; Istanbulluoglu et al. 2002; Takken et al. 2008; Henkle et al. 2011; Julian et al. 2012; Płaczkowska et al. 2015). In this study, the head channel area was calculated on the basis of the statistical analyses of physiographic parameters which significantly influence on the overland-flow formation process (e.g., Gil 1999; Han et al. 2012). This approach allowed to develop the models of the catchments contributing to the streams development.

The procedure has been performed as follows. During field-work carried out after heavy rainfall, the points where concentrated flow occurred were registered and the GPS coordinates were set (details are in the result sections). In this way, 37 catchments were delineated. Taking into account the literature describing mechanisms of the overland-flow formation process during heavy rainfall in the small flysch catchments (see Bryndal 2014a for review), 
such physiographic parameters as (1) the catchment area (ha), (2) the catchment mean slope gradient $\left({ }^{\circ}\right)$, land use land cover (LULC) structure (\%) including (3) arable lands, (4) forest, (5) grasslands, and (6) soil permeability $\left(\mathrm{mm} \cdot \mathrm{h}^{-1}\right)$ were selected. Parameters were calculated in GIS software as a result of the DEM, soil, and land cover layers analyses. The soil permeability index $k$ was attributed to bedrock lithology according to Pazdro and Kozerski (1990). In this way, each catchment was characterized by 6 parameters. The catchments were layout in a table, and the quartiles for each land cover (arable lands, forest, and grasslands) were calculated. At the next stage, from the set of all catchments, only those were selected, where the a given type (arable lands, forest, and grasslands) of the land cover was higher than the third quartile (calculated for a set of all catchments studied). In this way, the catchments in which a particular type of the land cover prevailed were selected. These groups were characterized by descriptive statistics (quartiles), calculated for the physiographic parameters and served as the models of the catchments contributing to the streams' development. The head channel area determined for the models (second quartile) was the threshold values for the stream initiation in GIS module. The threshold values of the head channel areas were then attributed to the land cover types. In this way, the so-called 'roughness map' was developed. A linkage between the 'roughness map' and the drainage lines map (developed on the base of the DEM) allowed to generate the first elements of the SDS, with regard to the spatial diversity of the land cover. The operations were performed using typical algorithms implemented in GIS software and standard procedures.

The comparison of the points where concentrated flow occurred (determined by GPS coordinates after rainfall) with the points delineated by GIS algorithm, allowed to evaluate the effectiveness of the approach proposed.

\section{Changes of the surface drainage system- quantitative assessment}

Development of the SDS operating during heavy rainfall allowed to compare it to the river system, which operates when the groundwater aquifer id drained. This gave the opportunity to analyse how the river system changes during these events. The river system was reconstructed on the basis of the topographic map 1:10,000 in scale. The analysis was performed in relation with a catchment scale as a whole, and sub-catchments drained by $i$-order stream, classified according to Strahlers' (1957) topology. The SDS was characterized by: the number $(n)$, frequency $\left(\mathrm{n} \cdot \mathrm{km}^{-2}\right)$, total length and mean stream length $(\mathrm{km})$, the density of a of streams $\left(\mathrm{km} \cdot \mathrm{km}^{-2}\right)$, catchments area and mean catchment area $\left(\mathrm{km}^{2}\right)$ drained by $i$-order streams and the bifurcation
$\left(R_{\mathrm{B}}\right)$, the length $\left(R_{\mathrm{L}}\right)$, and the area $\left(R_{\mathrm{A}}\right)$ ratios (Horton 1945; Schumm 1956).

\section{Results}

Creation of the surface drainage system.

\section{Models of the catchments contributing to the streams development}

The models have been developed according to the procedure described in the methodology section. The heavy rainfall took place in the night $26 / 27$ June 2009 , and resulted in flash floods in Zalasówka, Pożory, and Wattok catchments (Bryndal et al. 2010). The rainfall started at 7.30 PM and finished at 11.50 PM local time ( $+2 \mathrm{~h}$ UTC). The intensity reached $12 \mathrm{~mm} \cdot 10 \mathrm{~min}^{-1}$ and total sum amounted to $30 \mathrm{~mm}$. The rainfall parameters are significant in the context of applicability of the approach. For the flysch bedrocks, rainfall intensity exceeding $1 \mathrm{~mm} \cdot \mathrm{min}^{-1}$, is considered as a threshold value which predisposes the overland-flow formation process (Starkel 1996) and consequently the SDS development.

In case of the heavy rainfall, field investigation must be performed post factum, after the rainfall event, due to the fact, that it is difficult to predict when/where heavy rainfall may occur (Gaume and Borga 2008). When the investigations are performed immediately after torrential rainfall, water flow marks are clear, and it is relatively easy to identify points, where concentrated flow occurs. In this study, immediately after the rainfall event, the points where the concentrated flow occurred were mapped, and GPS coordinates were set. The points were identified by looking at micro-forms resulted from linear erosion of the flowing water or the water marks which were identifiable on the grass (grasslands) or the litter (forest areas). The field-work investigation was predominantly carried out on the hilltops, where the first elements of the SDS have been formed (Figs. 3, 4). It is worth to emphasise that most of the points were identified on the unpaved roads, which accumulated the overland flow from the upper part of the catchment (Fig. 3). In both catchments, 37 points were selected (from 70 mapped) for detail investigations. The points determined catchments that represented different conditions for the overland-flow formation processes.

The descriptive statistics $\left(Q_{10}-Q_{90}\right)$ calculated for 37 catchments are presented in Table 1 . The catchments contributing to the streams development are very small in area (area $<0.6$ ha for $75 \%$ catchments). The medium catchment gradient is between $3.4^{\circ}$ and $10.1^{\circ}$, for $75 \%$ of the catchments. The arable lands were identified in 30 per 37 catchments. For $50 \%$ of these catchments, the arable land 

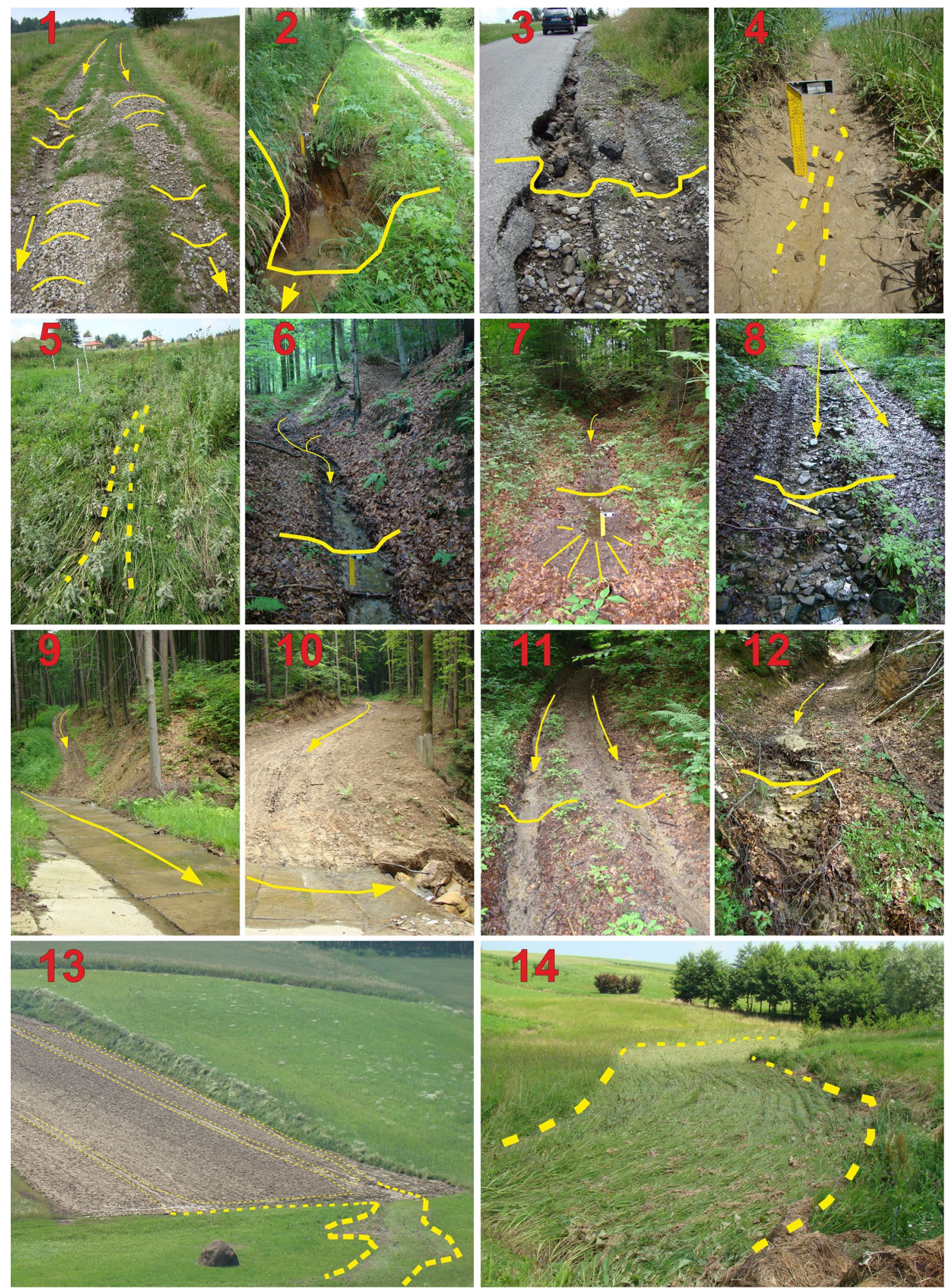

Fig. 3 The examples of the concentrated type of the overland flow, registered in the Zalasówka and Pożory catchments after heavy rainfall in the night 26/27 June 2009. Numbers of photos are marked on Fig. 4. Source: authors' own elaboration 
Fig. 4 The surface drainage system classified according to Strahler (1957) topology. Generated on the basis of topomap 1:10 000-A, generated on the basis of DEM according to methodology proposed in this study-B. Source: authors' own elaboration

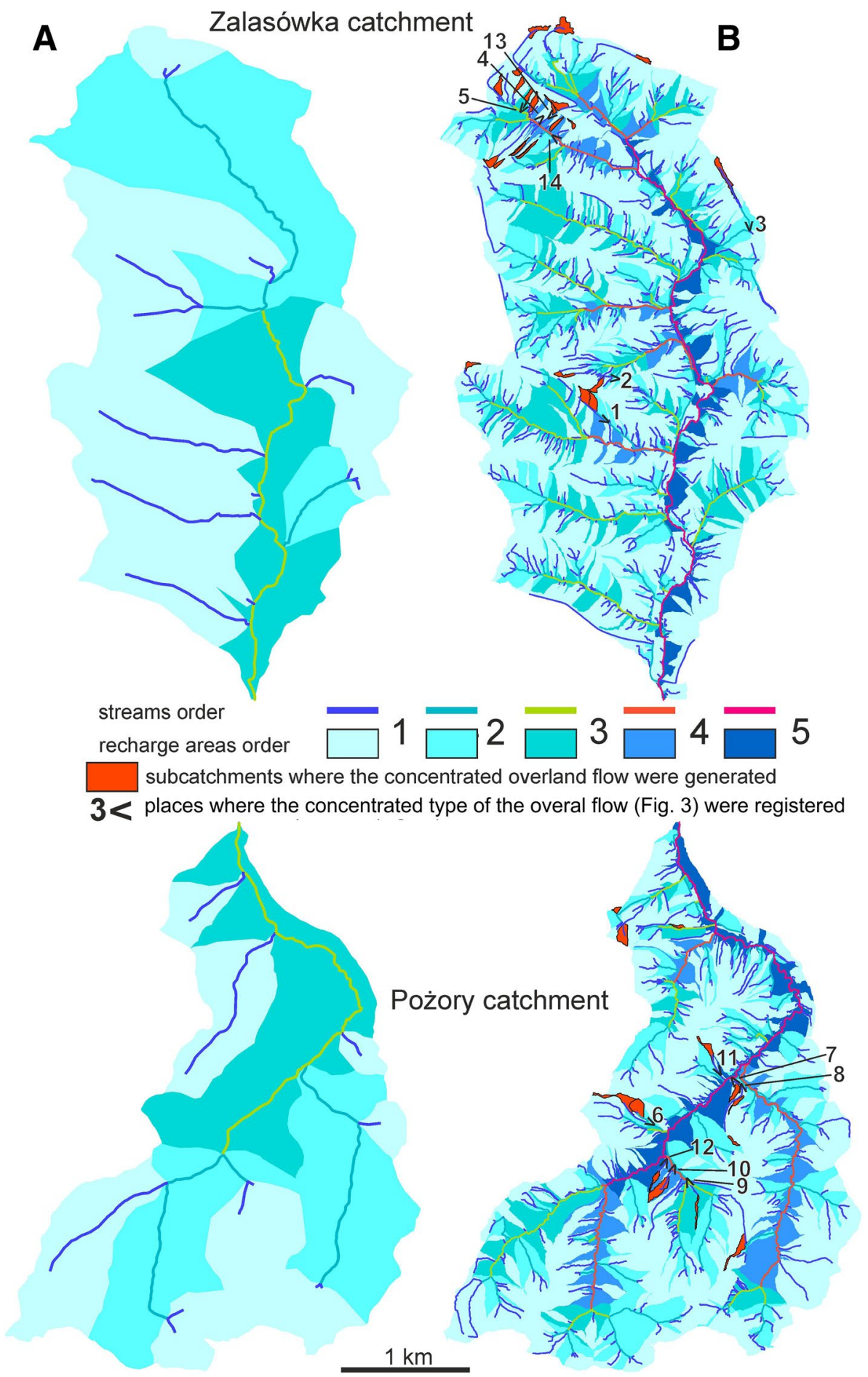

content is higher than $67.9 \%$. Forest was identified in the 11 per 37 catchments. For $50 \%$ of the catchments studied, the forest content is higher than $84.7 \%$. Grasslands were identified in 26 per 37 catchments. The grassland content was usually lower than $13.3 \%$. Only 6 per 26 catchments had this content higher than $47.9 \%$. The soil cover in both catchments was comparable in terms of permeability (30-36 $\mathrm{mm} \mathrm{h}^{-1}$ ), due to high clay mineral content (>40\%) in loess and clay bedrocks. The descriptive statistics calculated for the models of catchments contributing to the streams development are presented in Table 2. The second quartile for the head channel area was the threshold value in the SDS reconstruction. For the forest areas, the threshold value reached 0.88 ha. For the grassland and arable lands, the values reached 0.45 and 0.29 ha, respectively. 
Table 1 Physiographic parameters of the catchments, where first elements of the surface drainage system were developed

Table 2 Models of catchments contributing to the streams development

\begin{tabular}{|c|c|c|c|c|c|c|}
\hline Parameter & $N$ & $Q_{10}$ & $Q_{25}$ & $Q_{50}$ & $Q_{75}$ & $Q_{90}$ \\
\hline \multicolumn{7}{|c|}{ Dimensions, relief, bedrock properties } \\
\hline Area (ha) & 37 & 0.2 & 0.3 & 0.4 & 0.6 & 1.1 \\
\hline Mean slope gradient $\left(^{\circ}\right)$ & 37 & 3.4 & 5.1 & 7.2 & 10.1 & 12.2 \\
\hline Soil permeability $\left(\mathrm{mm} \mathrm{h}^{-1}\right)$ & 37 & 30 & 34 & 36 & 36 & 36 \\
\hline \multicolumn{7}{|l|}{ Land cover } \\
\hline Arable lands (\%) & 30 & 5.4 & 25.3 & 67.9 & 91.4 & 98.8 \\
\hline Forest $(\%)$ & 11 & 23.2 & 42.2 & 84.7 & 95.3 & 95.4 \\
\hline Grasslands (\%) & 26 & 2.8 & 6.6 & 13.3 & 47.9 & 67.0 \\
\hline
\end{tabular}

Source: This study. $N$ number of valid observation, $Q_{10}-Q_{90}$ percentiles

\begin{tabular}{|c|c|c|c|c|c|c|c|c|}
\hline \multirow[t]{2}{*}{ Model } & \multirow[t]{2}{*}{$\begin{array}{l}\text { Dominated type } \\
\text { of the land cover }\end{array}$} & \multirow[t]{2}{*}{$N$} & \multicolumn{3}{|c|}{$\begin{array}{l}\text { Quartiles for } \\
\text { the dominated } \\
\text { type of the } \\
\text { land cover }(\%)\end{array}$} & \multirow[t]{2}{*}{$\begin{array}{l}Q_{2} \text { for the medium } \\
\text { slope gradient }\left(^{\circ}\right)\end{array}$} & \multirow[t]{2}{*}{$\begin{array}{l}Q_{2} \text { for the soil } \\
\text { permeability ( } \mathrm{mm} \\
\mathrm{h}^{-1} \text { ) }\end{array}$} & \multirow[t]{2}{*}{$\begin{array}{l}Q_{2} \text { for the head } \\
\text { channel area } \\
\text { (ha) }\end{array}$} \\
\hline & & & $Q_{1}$ & $Q_{2}$ & $Q_{3}$ & & & \\
\hline I & Arable land & 9 & 92 & 97 & 100 & 5.4 & 34 & 0.29 \\
\hline II & Forest & 9 & 76 & 89 & 95 & 12.1 & 36 & 0.88 \\
\hline III & Grasslands & 9 & 48 & 51 & 67 & 7.3 & 30 & 0.45 \\
\hline
\end{tabular}

Source: This study. $N$ number of valid observation, $Q_{1}-Q_{3}$ quartiles

\begin{tabular}{|c|c|c|}
\hline & $N$ & $\begin{array}{l}\text { Quartiles cal- } \\
\text { culated for the } \\
\text { differences }^{\mathrm{a}} \\
\text { (m) }\end{array}$ \\
\hline & & $\begin{array}{lll}Q_{1} & Q_{2} & Q_{3}\end{array}$ \\
\hline Catchment & 37 & $\begin{array}{lll}-67 & -4 & 33\end{array}$ \\
\hline
\end{tabular}

Source: This study. $N$ number of catchments

${ }^{a}$ Negative value denotes that the point, where stream had begun (delineated by GIS modules), was situated closer to the catchments' watershed, then the point measured during field work by GPS receiver; positive values have the opposite interpretation

\section{Creation of the surface drainage system}

The SDS was created according to the method described in the methodology section and models of catchments presented in Table 2. The differences between the points were concentrated flow occurred (determined by GPS coordinates after rainfall), and the points delineated by GIS algorithm are presented in Table 3. The negative values of the second and third quartiles indicate that the streams were delineated (by GIS algorithm) closer to the watershed. However, the differences reached, on average, only $-4 \mathrm{~m}$ (median). Only for $25 \%$ of the catchments, the differences were higher than
$67 \mathrm{~m}$ (regardless of the direction characterized by the positive or negative values of the quartiles). This comparison indicates that the approach proposed in this study allows to reconstruct the SDS, which operate during heavy rainfall in small flysch catchments.

\section{Changes in the surface drainage system}

Figure 4 presents the SDS in context of the so-called Hortonian type of analysis. Site A presents the river drainage system presented on the topographic map $(1: 10,000)$, which Site B presents the system operating during heavy rainfall (Fig. 4b), reconstructed by use of the approach proposed in this study. The system operating during heavy rainfall is better developed. The maximum stream order increased from third to fifth orders, in both catchments (Table 4). There is the significant increase in the number of streams in each stream order. The most noticeable changes are observed in the first-order streams. In the Zalasówka catchment (agricultural type), the number of the first-order streams increased 50 times (from 14 to 693). The increase in the second- and third-order streams was 52 (from 3 to 155) and 37 (from 1 to 37), respectively. In the Pożory catchment (agriculturalforested type), this increase was slightly lower. The number of the first-order streams increased 45 times (from 11 to 493). For the second- and third-order streams, this increase was 36 (from 3 to 108) and 20 (from 1 to 20), respectively. operates when the groundwater aquifer is drained (Fig. 4a). 
Table 4 Statistics of the surface drainage systems generated from topographic map 1:10 000 and DEM generated from LiDAR data according to procedure proposed in methodology section

\begin{tabular}{|c|c|c|c|c|c|c|c|c|c|c|c|c|}
\hline \multirow[t]{2}{*}{ Stream order } & \multicolumn{2}{|c|}{ Number of streams $(n)$} & \multicolumn{2}{|c|}{$\begin{array}{l}\text { Frequency (n } \\
\left.\mathrm{km}^{-2}\right)^{*}\end{array}$} & \multicolumn{2}{|c|}{$\begin{array}{l}\text { Total stream } \\
\text { length }(\mathrm{km})\end{array}$} & \multicolumn{2}{|c|}{$\begin{array}{l}\text { Mean stream length } \\
(\mathrm{km})\end{array}$} & \multicolumn{2}{|c|}{$\begin{array}{l}\text { Stream density } \\
\left(\mathrm{km} \mathrm{km}^{-2}\right)\end{array}$} & \multicolumn{2}{|c|}{$\begin{array}{l}\text { Mean catchment } \\
\text { area }\left(\mathrm{km}^{2}\right)\end{array}$} \\
\hline & Map & DEM & Map & DEM & Map & DEM & Map & DEM & Map & DEM & Map & DEM \\
\hline \multicolumn{13}{|c|}{ Zalasówka catchmets } \\
\hline 1 & 14 & 693 & 3.03 & 114.89 & 6.58 & 67.15 & 0.47 & 0.1 & 1.42 & 11.13 & 0.33 & 0.009 \\
\hline 2 & 3 & 155 & 1.05 & 108.82 & 3.78 & 22.17 & 1.26 & 0.23 & 1.33 & 15.57 & 2.49 & 0.048 \\
\hline 3 & 1 & 37 & 0.58 & 32.43 & 3.66 & 13.12 & 3.66 & 0.59 & 2.13 & 11.50 & 9.20 & 0.232 \\
\hline 4 & - & 7 & - & 19.20 & - & 4.57 & - & 1.24 & - & 12.53 & - & 1.280 \\
\hline 5 & - & 1 & - & 3.12 & - & 6.09 & - & 7.33 & - & 18.98 & - & 9.200 \\
\hline Average & $R_{\mathrm{B}}=3.8$ & $R_{\mathrm{B}}=5.2$ & 1.60 & 55.70 & - & - & $R_{\mathrm{L}}=2.8$ & $R_{\mathrm{L}}=3.2$ & 1.5 & 12.2 & $R_{\mathrm{A}}=5.6$ & $R_{\mathrm{A}}=5.7$ \\
\hline Sum & - & - & - & - & 14.0 & 113.1 & - & - & - & - & - & - \\
\hline \multicolumn{13}{|c|}{ Pożory catchment } \\
\hline 1 & 11 & 493 & 3.85 & 118.20 & 4.27 & 45.85 & 0.39 & 0.09 & 1.49 & 10.97 & 0.26 & 0.008 \\
\hline 2 & 3 & 108 & 1.22 & 78.78 & 4.00 & 17.66 & 1.72 & 0.25 & 1.63 & 12.88 & 1.77 & 0.051 \\
\hline 3 & 1 & 20 & 0.55 & 31.02 & 3.66 & 6.53 & 5.38 & 0.58 & 2.01 & 10.12 & 7.13 & 0.310 \\
\hline 4 & - & 5 & - & 9.58 & - & 6.10 & - & 1.80 & - & 11.69 & - & 1.343 \\
\hline 5 & - & 1 & - & 2.50 & - & 5.13 & - & 6.93 & - & 12.79 & - & 7.117 \\
\hline Average & $R_{\mathrm{B}}=3.3$ & $R_{\mathrm{B}}=4.7$ & 1.90 & 48.00 & - & & $\mathrm{R}_{\mathrm{L}}=3.8$ & $\mathrm{R}_{\mathrm{L}}=3.0$ & 1.70 & 11.40 & $\mathrm{R}_{\mathrm{A}}=5.4$ & $\mathrm{R}_{\mathrm{A}}=5.5$ \\
\hline Sum & - & - & - & - & 11.9 & 81.3 & - & - & - & - & - & - \\
\hline
\end{tabular}

Source: this study. $R_{B}, R_{L}, R_{A}$ the bifurcation ratio, the mean length ratio, the mean area ratio

*Calculated in relation with sub-catchment area drained exclusively by $i$-order stream

For the river system, the average rate of the development, characterized by the bifurcation ratio $R_{\mathrm{B}}$, reached 3.8 and 3.3 in the Zalasówka and Pożory catchment, respectively.
The rate of the bifurcation between consecutive $i$-order streams ranged between 3.0 and 4.7 (Zalasówka) and 3.7-3.0 (Pożory)—Fig. 5. During heavy rainfall, $R_{\mathrm{B}}$ increased to 5.2
A
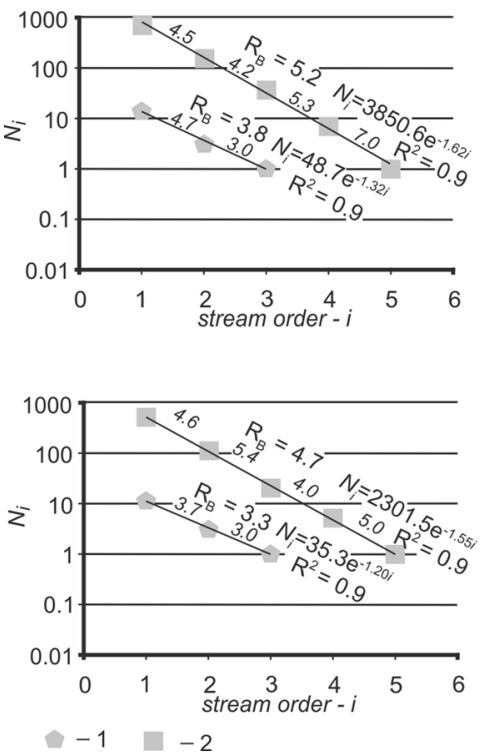

B Zalasówka catchment

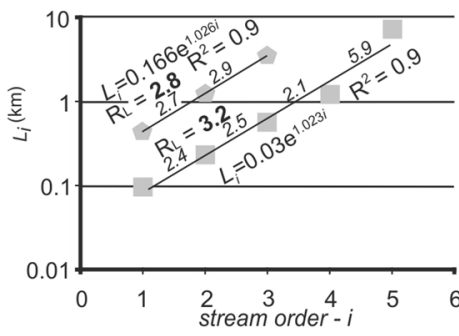

Pożory catchment

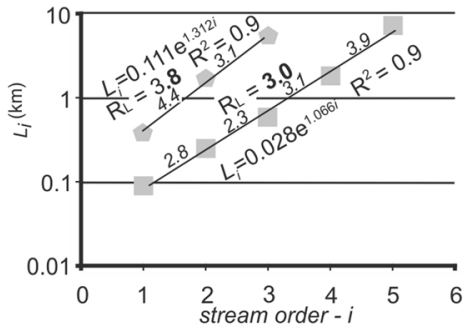

C
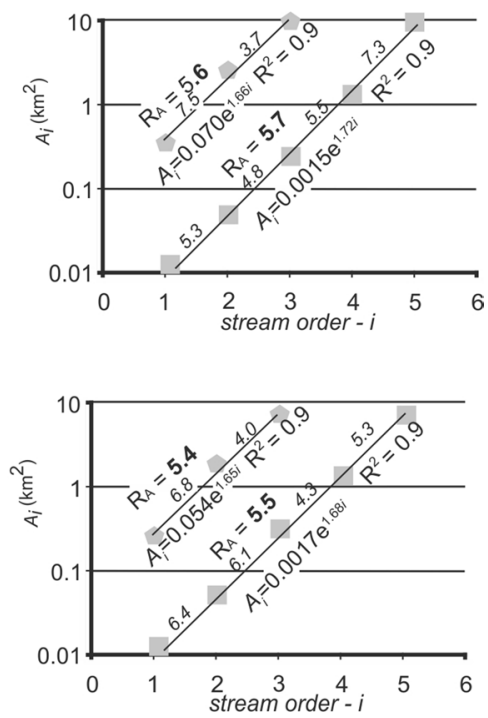

Fig. 5 The surface drainage system development in context of so called Hortonians' type of analysis. $\mathrm{R}_{\mathrm{B}}$-the bifurcation ratio (site $\mathrm{A}$ ), $\mathrm{R}_{\mathrm{L}}$-the mean length ratio (site $\mathrm{B}$ ), $\mathrm{R}_{\mathrm{A}}$-the mean area ratio (site $\mathrm{C}$ ), 1-the river system which drain the groundwater aquifer, 2-the surface drainage system operating during heavy rainfall. Source: authors' own elaboration 
in Zalasówka and 4.7 in Pożory. The slope of the regression line (Fig. 5a) indicated that the SDS developed 'slightly slower' Pożory catchment, which is more forested than the Zalasówka. Moreover, a lower rate of the drainage system development was observed for the river system, contrary to the SDS which operated during heavy rainfall.

The stream frequency $\left(\mathrm{n} \mathrm{km}^{-2}\right)$ allows to present the relative changes in the segments of the surface drainage system. The average frequency of the segments in the river system reached 1.6 and 1.9 per $\mathrm{km}^{2}$ in the Zalasówka and Pożory catchment, respectively. During heavy rainfall, the number of segments of the SDS increased 35 times in Zalasówka (55.7) and 25 times in Pożory (48.0) catchments (Table 4). There are internal differences in the frequency of the $i$-order segments. In both catchments for the river system, the frequency ranged between 0.55 and 3.85 segments per $\mathrm{km}^{2}$. During heavy rainfall, the frequency of the stream segments significantly increased. The increase was the most noticeable in the first-order streams, which accumulate stormflow water. In the Zalasówka catchment, the frequency of the first-order stream increased 38 times (from 3.03 to 114.89), whereas in the Pożory catchment, this increase reached 31 (from 3.85 to 118.2).

Apart from the number and the frequency of the streams, there is a significant increase in the summary length and the average density of the SDS. In the Zalasówka, the summary length increased from 14.0 to $113.1 \mathrm{~km}$, and the drainage density increased from 1.5 to $12.2 \mathrm{~km} \cdot \mathrm{km}^{-2}$ (Table 4). In the Pożory catchment, these parameters increased from 11.9 to $81.3 \mathrm{~km}$ and from 1.7 to $11.4 \mathrm{~km} \cdot \mathrm{km}^{-2}$, respectively. These measures indicate that the drainage system operating during heavy rainfall is c.a. 7-8 times denser, compared to the river system. The differences were also observed in relation with stream order, and the most significant changes were in the first-order streams, where total stream length increased c.a. 10 times, and the stream density increased c.a. 7 times (Table 4). In the second- and third-order streams, these increases were usually lower and ranged from 2 to 6 . It is worth to emphasis, that the density of the river system, related to $i$-order stream was lower than $2.13 \mathrm{~km}$ $\mathrm{km}^{-2}$, whereas during heavy rainfall, the density of the SDS exceeded $11.00 \mathrm{~km} \mathrm{~km}^{-2}$.

The mean length of the first-order streams in the river system, amounted to 0.47 and $0.39 \mathrm{~km}$ in the Zalasówka and Pożory catchment, respectively. The average increase of the mean stream length, characterized by the $R_{\mathrm{L}}$ ratio, reached 2.8 (Zalasówka) and 3.8 (Pożory) (Fig. 5). During heavy rainfall, the mean length of each $i$-order streams decreased. For the first-order stream, the mean length reached c.a. $0.1 \mathrm{~km}$, (in both catchments) and it was 4-5 times lower that the mean length calculated for the river system. It is worth to emphasis that, during heavy rainfall, the systems are similar up to third-order streams, regardless of the differences observed in land cover (Table 4). This similarity may be explained by the fact that the man-origin incisions (forest roads in the Pożory catchment-see Fig. 3) were incorporated to the drainage system. During heavy rainfall, the rate of the SDS development in both drainage systems is comparable, what has been confirmed by the $R_{\mathrm{L}}$ ratio (Zalasówka: 3.2 and Pożory: 3.0$)$ and the exponent in the regression line (Zalasówka: 1.026 and Pożory: 1.066) (Fig. 5b).

The mean area allows to characterize dimensions of the sub-catchment drained by $i$-order streams. For the river system, the mean area drained by the first-order stream, amounted to $0.33 \mathrm{~km}^{2}$ in the Zalasówka and $0.26 \mathrm{~km}^{2}$ in the Pożory catchment (Table 4). The area ratio $\mathrm{R}_{\mathrm{A}}$ was similar in both catchments (5.6 and 5.4 in the Zalsówka and Pożory catchments, respectively) (Fig. 5c). During heavy rainfall, the mean area drained by the first-order streams significantly decreased. In both catchments, this value reached c.a. $0.009 \mathrm{~km}^{2}$, and was $32-37$ times lower compared to the mean area calculated for the river system. The area ratio $R_{A}$ was comparable in both catchments (5.7 in Zalasówka and 5.4 lower in Pożory).

The analysis revealed that there are significant quantitative changes between the river system which operate when the groundwater aquifer is drained, and the SDS operating during heavy rainfall. Knowledge about the structure of the SDS operating during heavy rainfall complements the qualitative analysis. The structure (Table 5) and the examples how the man-origin elements are incorporated to the SDS are presented in Fig. 6. The man-origin sub-system constituted significant part of the SDS. In the Zalasówka catchment plough furrows, roads and ditches constituted 35\% of the SDS. In the Pożory catchment, this value reached $25 \%$. This lower content is due to the plough furrows content, resulting from the differences in the land cover (Fig. 1). In

Table 5 Structure of the surface drainage system operating during heavy rainfall

\begin{tabular}{|c|c|c|c|c|}
\hline & \multicolumn{2}{|c|}{ Zalasówka } & \multicolumn{2}{|c|}{ Pożory } \\
\hline & $\mathrm{km}$ & $\%$ & $\mathrm{~km}$ & $\%$ \\
\hline \multicolumn{5}{|l|}{$\begin{array}{l}\text { Natural-origin sub-system } \\
\text { Concentrated flow in }\end{array}$} \\
\hline Streams (Fig. 6a) & 11.9 & 11 & 13.9 & 18 \\
\hline Smaller lateral valleys (Fig. 6a) & 40.7 & 37 & 25.2 & 33 \\
\hline $\begin{array}{l}\text { Small incision/concavity on the } \\
\text { hillslopes conditioned by micro-relief } \\
\text { (Fig. 6b) }\end{array}$ & 18.2 & 17 & 18 & 24 \\
\hline \multicolumn{5}{|l|}{$\begin{array}{l}\text { Man-origin sub-system } \\
\text { Concentrated flow in }\end{array}$} \\
\hline Plough furrows (Fig. 6c) & 16.8 & 16 & 4.1 & 6 \\
\hline Roads and ditches (Fig. 6d) & 20.2 & 19 & 14 & 19 \\
\hline Total & 107.8 & 100 & 75.2 & 100 \\
\hline
\end{tabular}

Source: This study 
Fig. 6 The organization of the surface drainage system operating during heavy rainfall-the examples. Concentrated flow in the stream channels and gorges-A, concentrated flow in small incisions on the hillslopes conditioned by micro-relief-B (A, B-natural-origin sub-system), plough furrows-C, roads, ditches-D (C, D-man-origin sub-system). Source: authors' own elaboration based on orthophotos from CODGIK)

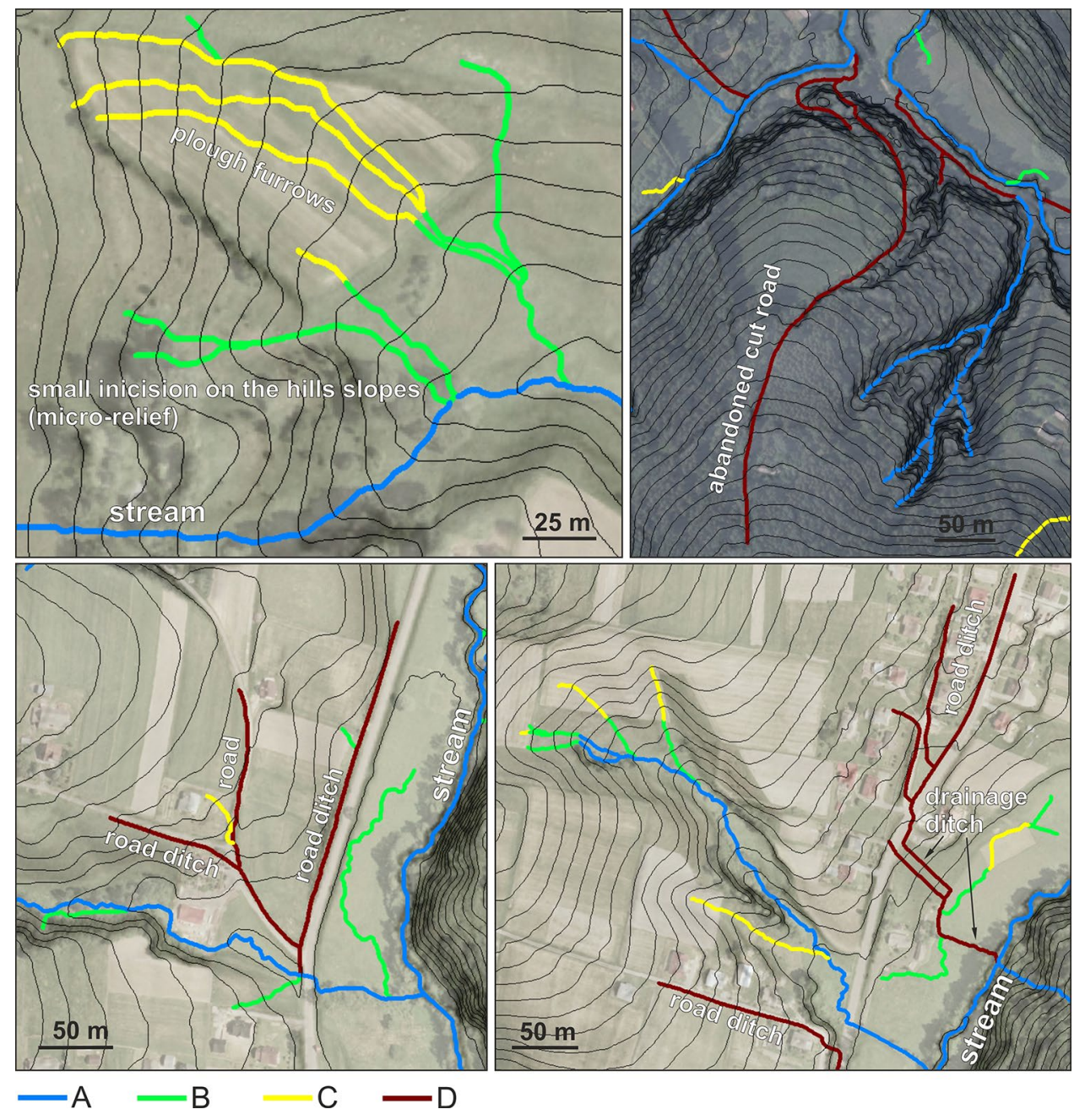

both catchments, the natural-origin sub-system prevailed; however, there are significant disproportions between the permanent and episodic elements. The rivers constituted up to $18 \%$ of the SDS operating during heavy rainfall. The most important part of the natural-origin sub-system was small lateral valleys, which constituted 33\% (Pożory) and 37\% (Zalasówka) of the SDS. Significant part, in the structure of the natural-origin sub-system constituted small incisions or concavities on the hillslopes conditioned by micro-relief. These forms usually collect the overland flow from plough furrows (Fig. 6).

\section{Discussion}

\section{The methodological aspects}

Lack of high-resolution DEMs hampered reconstruction of the SDS functioning during heavy rainfall. Consequently, it was difficult to analyse how the river system changes during these events. Globally available models such as: SRTM and ASTER detect only larger natural forms such as ridges and valleys. Better results were obtained using topographic maps, models generated from orthophotos, airborne interferometric methods, etc. However, methodological requirements allow to develop the DEMs with the resolution $5 \times 5 \mathrm{~m}$. This resolution did not allow to reproduce smaller incisions such as minor roads, ditches, plug furrows, etc. (Shore et al. 2013; Kroczak and Bryndal 2015), which operate as the episodic drainage lines during heavy rainfall. The LIDAR data, released in recent years, give new opportunity in this research field. The approach proposed in this study shows how to use ALS-LIDAR data for investigation of the changes in the SDS.

Use of the LIDAR data eliminated the necessity of burning streams into the DEM to improve hydrological analyses, as it was typical practice. However, it implied a new task-removing the artificial dams, which disturb natural gravity flow, and prevent to develop hydrologically correct DEM what is especially important for detail analyses. This process requires detail location and characterization of the artificial dams. In many mountain areas, where the LIDAR 
data are available, there are databases, where all artificial dams (bridges/culverts) are described by the GPS coordinates (e.g., Lidberg et al. 2017). In such areas, creation of hydrologically correct DEM with use of the LIDAR data and creation of the SDS is a relatively easy procedure. It is worth to mention that most of these areas are usually forested and the road network density range from 1 to $2 \mathrm{~km} \cdot \mathrm{km}^{-2}$ (e.g., Wemple et al. 2001, 2017; Croke et al. 2005; Takken et al. 2008; Lidberg et al. 2017). Moreover, the roads were built mainly to extract timber and projected for use by heavy vehicles (Luce and Wemple 2001). In the Carpathians, the situation is more complicated. The arable lands dominate in the structure of land use and the parcels are very small. The average size of single parcel reached 0.5 ha in the Zalasówka and 1.4 ha in Pożory catchment (LPIS 2017). This resulted in development of dense road network which range from 7.4 to $8.4 \mathrm{~km} \cdot \mathrm{km}^{-2}$ (Kroczak et al. 2016). Most of the roads are unpaved $(80 \%)$ and relatively narrow $(2-3 \mathrm{~m})$. This fact implicates enormous number of local artificial dams (generally culverts), which are not incorporated to any databases available for GIS studies. In authors' opinion, in such conditions, field work provides the most detailed input data required for the DEM optimization and reconstruction of the SDS. Some alternative approach, but less accurate is the identification of the artificial dams using shaded 3D-view of the LIDAR-origin DEM (optionally covered by orthophotos). In this approach, the parameters required for characterization of bridge/culverts may be measured indirectly in GIS software.

In SDS reconstruction process, the important thing is the selection of the GIS algorithm. There are many algorithms developed and implemented in GIS modules supporting hydrological analysis, which facilitate the development of lines, where gravity flow water may occur (see, e.g., Milligan 2014 for theoretical explanation). Taking into account the goals of the study, the most preferable is the D8 algorithm, in which only one direction of the water flow is selected as an output from the matrix of the pixels analysed (O'Callaghana and Mark 1984). In the areas, where the relative height is low, the drainage lines may be generated imprecisely (often as perpendicular lines). This is often highlighted as a disadvantage using D8 algorithm, and therefore, many modifications of this algorithm (e.g., D8-LTD, MFD-Multiple Flow Direction, Random eight node, D-infinity, DEMON-Digital Elevation Model Networks) were proposed (e.g., Turcotte et al. 2001; Milligan 2004 review; Hengl and Router 2009). In authors' opinion, the disadvantage of the basic version of the D8 algorithm supports reconstruction of the SDS on the ALS-LiDARbased DEM. It allows to detect even small perpendicular incisions (e.g., plough furrows, roads) which are man-origin elements, and incorporate them to the SDS. Therefore, the D8 algorithm was selected for the purpose of this study.
The novelty of the approach proposed in this study is the parameterization of the catchments, contributing to the drainage system creation. In the geomorphological studies, the places where the channel begins were usually determined empirically (e.g., Kirby 1980; Julian et al. 2012-review). In some works, these places were determined using probabilistic approach (e.g., Istanbulluoglu et al. 2002). These solutions give good results in natural catchments (Henkle et al. 2011; Julian et al. 2012). When man-origin lines (especially roads) modify runoff pattern their applicability may be limited. Therefore, the models of the catchment contributing to the streams development were developed, on the basis of statistical analyses of physiographic parameters which significantly influence on the overland-flow formation process (e.g., Gil 1999; Han et al. 2012). This approach allowed to generate the first elements of the SDS, with regard to the spatial diversity of the land cover. Use of the field-based and GIS approach proposed in this study allowed to reconstruct the SDS, which operate during heavy rainfall.

\section{Changes in the surface drainage system and their consequences in catchment functioning}

Changes in the SDS are the most noticeable during heavy rainfall and affect many hydrological processes. These are mainly related to acceleration of the water cycle on the hillslopes and the catchment (e.g., Loaugue and VanderKwaak 2002; Mirus and Loague 2013; Bryndal 2014a, b). For the natural catchments, the density of the SDS in mountain areas is usually up to $3.5 \mathrm{~km} \mathrm{~km}^{-2}$ (e.g., Bryndal 2014a, b; Kroczak et al. 2016), and the $R_{\mathrm{B}}, R_{\mathrm{L},} R_{\mathrm{A}}$ ratios are in the range 3-5, 1.5-3.5, 3-6, respectively (e.g., Smart 1972; Rodriguez-Iturbe and; Escobar 1982). The parameters of river systems in the Zalasówka and Pożory catchments are within these ranges. However, during heavy rainfall, the SDS is several times better developed, what is reflected in the stream density (increase to $12.2 \mathrm{~km} \cdot \mathrm{km}^{-2}$ ) and so-called Hortonian's ratios. It is worth emphasising that the most significant changes were related to the first- and second-order streams, which are small in size natural (conditioned by micro-relief) and man-origin (plough furrows, ditches, and unpaved roads) incisions predominantly (Fig. 6). For example, the number of first-order streams increases on average in both catchments 47 times and the mean length in the first-order streams decreases form c.a. $0.4 \mathrm{~km}$ (for the river system) to $0.1 \mathrm{~km}$ (during heavy rainfall). In general, sub-catchment drained by the first-order streams during heavy rainfall $\left(6.0 \mathrm{~km}^{2}\right.$ and $4.2 \mathrm{~km}^{2}$ in the Zalasówka and Pożory catchments, respectively) is c.a. 1.35 times larger, compared to the sub-catchment drained by first-order streams $\left(4.6 \mathrm{~km}^{2}\right.$ and $2.8 \mathrm{~km}^{2}$ in the Zalasówka and Pożory catchments, respectively) when the rivers drain the catchment. The incorporation of small in size natural and man-origin incisions to the SDS results 
in better drained of the slopes, because the stormwater is moved directly to the first-order streams. Incorporation of these incisions results in the increase in the overlandflow velocity and consequently hydrological response of a catchment. For example, the overland-flow velocity on Carpathian's flysch slope ranging from $10^{\circ}$ to $17^{\circ}$ may reach more than $100 \mathrm{~cm} \cdot \mathrm{s}^{-1}$ on the unpaved roads, but only 8-9 $\mathrm{cm} \cdot \mathrm{s}^{-1}$ on grassland fields and $13 \mathrm{~cm} \cdot \mathrm{s}^{-1}$ on ploughed fields (Figuła 1955). Similar flow velocity as was recorded on the unpaved roads may be expected within the man-made incisions such as plough furrows and ditches (which reach up to $35 \%$ of the SDS operating during heavy rainfall) and natural small incisions/concavities on the hillslopes conditioned by micro-relief (which reach up to $24 \%$ of the SDS operating during heavy rainfall). Taking into account that the quantitative and qualitative changes of the SDS operating during heavy rainfall, its influence on quick hydrological response of the catchment may be important. This influence may be confirmed by the fact, that in the catchments studied, several flash floods have occurred (Bryndal et al. 2010; Kroczak and Bryndal 2015). To investigate this influence, the authors made the attempt to reconstruct flood wave parameters after the rainfall 26/27 June 2009 in the Zalasówka catchment using SCS-CN and GIUH models (Rodríguez-Iturbe and Valdes 1979; Mistra and Singh 2003). The results revealed that GIUH model has better fit the hydrograph when $R_{\mathrm{B}}$, $R_{\mathrm{L}}$ and $R_{\mathrm{A}}$ described the "real" SDS which operated during heavy rainfall (Kroczak and Bryndal 2015). This preliminary results are promising and similar research may be taken in other experimental catchments.

Changes in the SDS resulted from incorporation of small in size natural and man-origin incisions may contribute to erosion and fragmentation of the hillslopes (e.g., Luce and Wemple 2001; Kroczak et al. 2015-review; Galia at al. 2017), delivery of the sediment material and its transportation to the river channel (e.g., Dietrich et al. 1987; Batalla et al. 1995; Froehlich and Słupik 1986; Froehlich and Walling 1997; Motha et al. 2004; Croke et al. 2005; Roy and Sahu 2017; Wemple et al. 2017). Erosional transformations of the hillslopes were observed in both catchments (Fig. 3). It is worth emphasising that erosional effects occur naturally during heavy rainfall (e.g., Gil 1999; Gaume and Borga 2008); however, the most significant erosional effects are usually observed on the man-origin incisions such as roads (especially unpaved) and ditches, where high-speed concentrated flow occurs. This was also observed after the heavy rainfall and flash flood in Zalasówka and Pożory catchments (see Fig. 6). The elements perform a significant role in transformation of the contemporary Carpathians hillslopes during extreme hydro-meteorological events, what was confirmed in the literature many times (e.g., Łajczak et al. 2014; Bryndal et al. 2017). The erosional changes were not investigated quantitatively, but taking into account the studies in similar
Carpathian's catchment, some consequences of the SDS alteration and its functioning during heavy rainfall may be sketched. The Bystrzanka catchment is one of the examples. During two heavy rainfall events, recorded in 2010 (which resulted in flash floods), $96 \%$ of the average yearly suspended sediment load, were carried out from the catchment, and man-origin incisions played an important role in delivering and transportation of suspended material to the main stream (Kijowska-Strugała et al. 2017). During the second flash flood, the suspended sediment load concentration, recorded at the mouth of the catchment reached $44 \mathrm{~g} \mathrm{dm}^{3}$, and it was the highest value recorded during the last 40 years (Kijowska-Strugała 2015). Man-origin incisions were also the main source of this material. The concentration of the suspended material at the unpaved road may be several times higher. In the Homerka catchment, this value reached 147.9 $\mathrm{g} \mathrm{dm}^{-3}$ (Froehlich 1982). In this catchment, unpaved roads contribute up to $80 \%$ of the total suspended sediment load (Froehlich 1991). This important geomorphological role of the man-origin incisions is also reported in other catchments located in mountain regions. For example, in the Winooski River catchment (USA), 53\% of the road network is hydrologically integrated with streams and the unpaved roads contribute to $31 \%$ of the annual suspended sediment load (Wemple et al. 2017). When the man-origin sub-system is less developed the influence on sediment delivery may be less noticeable. Batalla et al. (1995) suggest that in Arbúcies River catchment (Spain) only 10\% of the total sediment yield was due to the road system.

\section{Conclusions}

The main conclusions of this study may be as follows:

\section{Methodological aspects}

1. In this study, the field-based and GIS-integrated approach, allowing the reconstruction of the SDS operating during heavy rainfall, with use of the ALS-LIDAR data, has been proposed. Incorporation of these incisions requires development of high-resolution $(0.5 \times 0.5 \mathrm{~m})$, hydrologically correct DEM and the models of the catchment contributing to stream development. The methodology has been tested in two small flysch Carpathians catchments. The results are promising, and the SDS operating during heavy rainfall has been reconstructed accurately.

2. In authors' opinion, the approach proposed in this study may be applicable to similar studies. The optimization procedure is universal for all DEMs created on the basis of the ALS-LIDAR data. The head channel areas calculated for the models may be transferred to other flysch 
catchments located under temperate climate conditions, where man-origin incisions are well developed, and mechanisms of the overland-flow formation are comparable. This statement may be confirmed by three arguments:

(a) The source data used for development of the models were collected after the rainfall with intensity exceeding $1 \mathrm{~mm} \mathrm{~min}{ }^{-1}$. This value is considered as a threshold value predisposing the overland-flow formation process for the flysch bedrocks rich in clay minerals ( $>40 \%)$ and consequently development of the SDS.

(b) The models have been developed on the basis of the statistical analysis and taken into account diversity of the physiographic parameters, that affects the overland-flow formation processes at a small scale.

(c) The errors resulted from delineations of the SDS by GIS algorithm, on average, have been lower than $4 \mathrm{~m}$. This level of uncertainty, may be accepted for the reconstruction of the SDS and analysis of the SDS parameters at the catchment scale investigations.

\section{Changes in the surface drainage system and expected influence on a catchment functioning}

1. The reconstruction of the SDS gave the opportunity for analysis of the changes in this SDS during heavy rainfall. The system is several times better developed than the river system. Moreover, the structure of the SDS has changed, what was confirmed by the parameters of the Hortonian-type analyses. The most significant changes were related to the first- and second-order streams. These streams were, the most frequently, the man-origin incisions and natural-origin incisions/concavities on the hillslopes conditioned by micro-relief. The man-origin sub-system reached up to $35 \%$ of the SDS functioning during heavy rainfalls, whereas the sub-system composed of incisions/concavities conditioned by microrelief reached up to $24 \%$ of the SDS functioning during heavy rainfalls. The permanent streams and small lateral valleys constitute the remaining part of the SDS result in the hillslopes are better drained, and the water cycle is accelerated. As a result, the susceptibility of a catchment to flash flood formation may increase. This statement may be confirmed by the fact, that in the catchments studied, several flash floods have occurred.

2. Many studies confirmed that the man-origin incisions are the main source of the suspended material and they are responsible for transportation of this material within the catchment. The integrated field-based and GIS approach propose in the study, enable to determine the structure and parameters of the SDS functioning dur- ing heavy rainfall. Knowledge about parameters of the SDS may contribute to explanation of geomorphological aspect related to the catchment functioning.

3. Use of the Horton's $R_{\mathrm{B}}, R_{\mathrm{L}}$, and Schumms' $R_{\mathrm{A}}$ ratios gave the opportunity for quantitative analysis of the changes in the SDS. The ratios are also the input data in many hydrological models. In authors' opinion, the parameters characterizing the SDS in hydrological models should describe SDS which operates in "real" condition not only natural-origin system obtained from the topographic maps, what is typical approach in practice. Characterization of the real SDS improves reconstruction/prediction of the flood wave in small ungauged catchments. In this context, the integrated field-based and GIS approach proposed in this study, enabling the reconstruction of the 'real' SDS, may have wide range of application both in hydrological and geomorphological studies.

Open Access This article is distributed under the terms of the Creative Commons Attribution 4.0 International License (http://creativeco mmons.org/licenses/by/4.0/), which permits unrestricted use, distribution, and reproduction in any medium, provided you give appropriate credit to the original author(s) and the source, provide a link to the Creative Commons license, and indicate if changes were made.

\section{References}

Batalla RJ, Sala M, Werrity A (1995) Sediment budget focused in solid material transport in a subhumid Mediterranean drainage basin. Zeitschrift fur Geomorphologie 39(2):249-269

Bryndal T (2014a) A method for identification of small Carpathian catchments more prone to flash flood generation. Based on the example of south-eastern part of the Polish Carpathians. Carpathian J Earth Environ Sci 9(3):109-122

Bryndal T (2014b) Identification of small catchments prone to flash flood generation in the Polish Carpathians. Prace Monograficzne Uniwersytetu Pedagogicznego 690:3-180 (in Polish with English summary)

Bryndal T, Cabaj W, Gębica P, Kroczak R (2010) Flash floods inducted by heavy rainfall in the Watok catchment (Ciężkowickie Foothills). In: Ciupa T, Suligowski R (eds) Water in geographical investigations. IGUJK, Kielce, pp 307-319

Bryndal T, Franczak P, Kroczak R, Cabaj W, Kołodziej A (2017) The impact of extreme rainfall and flash floods on the flood risk management process and geomorphological changes in small Carpathian catchments: a case study of the Kasiniczanka river (Outer Carpathians, Poland). Nat Hazard 88:95-120. https://doi. org/10.1007/s11069-017-2858-7

Croke J, Mockler S, Fogarty P, Takken I (2005) Sediment concentration changes in runoff pathways from a forest road network and the resultant spatial pattern of catchment connectivity. Geomorphology 68(3-4):257-268

Daniel JRK (1981) Drainage density as an index of climatic geomorphology. J Hydrol 50:147-154

Dietrich WE, Reneau SL, Wilson CJ (1987) Overview: zero-order basins and problems of drainage density, sediment transport and hillslope morphology. Int Assoc Hydrol Sci 165:49-59 
Directive (2007) 60/EC of the European Parliament and of the Council of 23 October 2007 on the assessment and management of flood risks. Off J Eur Union L 288:27-34

Figuła K (1955) Preliminary assessment of erosion on the several districts of the Krakowskie province. Roczniki Nauk Rolniczych $1: 1-80$ (in Polish)

Froehlich W (1982) Mechanism of fluvial transport and delivering of the mantle to the channel of flysch mountain catchment. Prace Geograficzne IGiPZ PAN 143:1-144 (in Polish)

Froehlich W (1991) Sediment production from unmetalled road surfaces, sediment and stream water quality in a changing environment: trends and explanation. IAHS Publ 203:21-30

Froehlich W, Słupik J (1986) The role of roads in the flow and erosion formation in the flysch Carpathian basins. Przegląd Geograficzny 58(1-4):67-85 (in Polish)

Froehlich W, Walling DE (1997) The role of unmetalled roads as a sediment source in the fluvial systems of the Polish Flysch Carpathians, human impacts on erosion and sedimentation. IAHS 245:159-169

Galia T, Šilhán K, Škarpich V (2017) The geomorphic impacts of culverts at paved forest roads: examples from Carpathian headwater channels. Czech Repub Catena 157:424-435. https://doi. org/10.1016/j.catena.2017.06.007

Gaume E, Borga M (2008) Post-food field investigations in upland catchments after major flash foods: proposal of a methodology and illustrations. J Flood Risk Manag 1:175-189

Gil E (1999) Water circulation and washout on the flysch agricultural hillslopes in the years 1980-1990. Zeszyty IGiPZ PAN 60:1-78 (in Polish with English summary)

Han S, Xu D, Wang S (2012) Runoff formation from experimental plot, field, to small catchment scales in agricultural North Huaihe River Plain, China. Hydrol Earth Syst Sci 16:3115-3125. https://doi. org/10.5194/hess-16-3115-2012

Hellweger F, Maidment D (1997) AGREE-DEM surface reconditioning system. http://www.ce.utexas.edu/prof/maidment/gishydro/ferdi/ research/agree/agree.html. Accessed 5 May 2017

Hengl T, Reuter HI (2009) (ed) Geomorphometry: concepts, software, applications. Dev Soil Sci 33:1-772

Henkle JE, Wohl E, Beckman N (2011) Locations of channel heads in the semiarid Colorado Front Range. USA Geomorphol 129(34):309-319. https://doi.org/10.1016/j.geomorph.2011.02.026

Horton RE (1945) Erosional development of streams and their drainage basins; hydrophysical approach to quantitative morphology. Geol Soc Am Bull 56(3):275-370

Istanbulluoglu E, Tarboton D, Pack R, Luce C (2002) A probabilistic approach for channel initiation. Water Resour Res 38(12):611-61-14. https://doi.org/10.1029/2001WR000782

Julian JP, Elmore AJ, Guinn SM (2012) Channel head locations in forested watersheds across the mid-Atlantic United States: a physiographic analysis. Geomorphology 177-178:194-203

Kijowska-Strugała M (2015) Transport of suspended sediment in the Bystrzanka stream (Polish Flysch Carpathians) under changing antropopressure. Prace Geograficzne IGiPZ PAN 247:1-140 (in Polish with English summary)

Kijowska-Strugała M, Wiejaczka $Ł$, Gil E, Bochenek W, Kiszka K (2017) The impact of extreme hydro-meteorological events on the transformation of mountain river channels (Polish Flysch Carpathians). Z Geomorphol 61(1):75-89

Kirkby MJ (1980) The stream head as a significant geomorphic threshold. In: Coates DR, Vitek AD (eds) Thresholds in geomorphology. Allen\&Unwin, London, pp 53-73

Kroczak R (2010) Geomorphological and hydrological effects of unmetalled road network functioning on the example of Ciężkowickie Foothills. Prace Geograficzne IGiPZ PAN 225:1138 (in Polish with English summary)
Kroczak R. Bryndal T (2015) An attempt to assess the influence of road network on flash flood wave parameters. The case study of the Carpathian Foothills. In: Jasiewicz J, Zwoliński Z, Mitasova H, Hengl T (eds) Geomorphometry for Geosciences, AM University in Poznań-Inst of Geoecol and Geoinformation. International Society for Geomorphometry, Poznań, pp 197-200

Kroczak R, Bryndal T, Bucała A, Fidelus J (2016) The development, evolution and environmental influence of an unpaved road network on mountain terrain — an example from the Carpathian Mts. (Poland). Environ Earth Sci 75(3):1-14

Łajczak A, Margielewski W, Rączkowska Z, Święchowicz J (2014) Contemporary geomorphic processes in the Polish Carpathians under changing human impact. Episodes 37(1):21-32

Lanfranc M, Van Dijk P, Jetten V, Schwob M, Payraudeau S (2017) Improving runoff prediction using agronomical information in a cropped, loess covered catchment. Hydrol Process 31(6): 1408-1423

Lidberg W, Nilsson M, Lundmark T, Ågren AM (2017) Evaluating preprocessing methods of digital elevation models for hydrological modelling. Hydrol Process 31(26):4660-4668

Lindsay JB (2016) The practice of DEM stream burning revisited. Earth Surf Proc Landf 41(5):658-668

Loaugue K, VanderKwaak JE (2002) Simulating hydrologic response for the R-5 catchment: comparison of two models and the impact of the roads. Hydrol Process 16:1015-1032

LPIS - Land-parcel identification system in Poland. Agencja Restrukturyzacji i Modernizacji Rolnictwa, Departament Baz Referencyjnych. http://www.geoportal.gov.pl/web/guest/DOCHK Access 02 May 2017

Luce $\mathrm{CH}$, Wemple BC (2001) Introduction to special issue on hydrologic and geomorphic effects of forest roads. Earth Surf Proc Landf 26:111-113

Milligan M (2004) Modeling catchment hydrology. In: Wainwright J, Mulligan M (eds) Environmental modeling. Finding simplicity in complexity. Willey, Chichester, pp 104-122

Mirus BB, Loague K (2013) How runoff begins (and ends): Characterizing hydrologic response at the catchment scale. Water Resour Res 49(5):2987-3006

Mistra SK, Singh VP (2003) Soil conservation service curve number (SCS-CN) methodology. Kluwer Academic, Dordrecht

Montgomery DR, Dietrich WE (1988) Where do channels begin? Nature 336(6196):232-234

Motha JA, Wallbrink PJ, Hairsine PB, Grayson RB (2004) Unsealed roads as suspended sediment sources in an agricultural catchment in south-eastern Australia. J Hydrol 286(1-4):1-18

O'Callaghan JF, Mark DM (1984) The extraction of drainage networks from digital elevation data. Comput Vis Graph Image Process 28(3):323-344

Pazdro Z, Kozerski B (1990) Hydrogeology. PWN, Warszawa

Płaczkowska E, Górnik M, Mocior E, Peek B, Potoniec P, Rzonca B, Siwek J (2015) Spatial distribution of channel heads in the Polish Flysch Carpathians. Catena 127:240-249

Rodríguez-Iturbe I, Valdes JB (1979) The geomorphologic structure of hydrologic response. Water Resour Res 15:1409-1420

Rodríguez-Iturbe I, Escobar LA (1982) The dependence of drainage density on climate and geomorphology. Hydrol Sci J 27(2):129-137

Rodríguez-Iturbe I, Muneepeerakul R, Bertuzzo E, Levin SA, Rinaldo A (2009) River networks as ecological corridors: a complex systems perspective for integrating hydrologic, geomorphologic, and ecologic dynamics. Water Resour Res 45:1944-7973

Roy S, Sahu AS (2017) Potential interaction between transport and stream networks over the lowland rivers in Eastern India. J Environ Manag 197:316-330

Schumm SA (1956) Evolution of drainage systems and slopes in badlands and Perth Amboy, NJ. Geol Soc Am Bull 67:597-646 
Shore M, Murphy PNC, Jordan P, Mellander PE, Kelly-Quinn M, Cushen M, Melland AR (2013) Evaluation of a surface hydrological connectivity index in agricultural catchments. Environ Model Softw 47:7-15

Słupik J (1976) Use of the aerial photos for evaluation of the furrows and roads on the water circulation on the mountain hillslopes. Prace Nauk UŚ 126 Fotointerpretacja w Geogr 11:31-38. (in Polish)

Smart JS (1972) Quantitative characterization of channel network structure. Water Resour Res 8(6):1487-1496

Starkel L (1996) Geomorphic role of extreme rainfalls in the Polish Carpathians. Studia Geomorphologica Carpatho-Balcanica 30:21-38

Strahler AN (1957) Quantitative analysis of watershed geomorphology. Eos Trans Am Geophys Union 38(6):913-920

Takken I, Croke J, Lane P (2008) Thresholds for channel initiation at road drain outlets. Catena 75(3):257-267

Thomas IA, Jordan P, Shine O, Fenton O, Mellander PE, Dunlop P, Murphy PNC (2017) Defining optimal DEM resolutions and point densities for modelling hydrologically sensitive areas in agricultural catchments dominated by microtopography. Int J Appl Earth Obs 54:38-52

Turcotte R, Fortin JP, Rousseau AN, Massicotte S, Villeneuve JP (2001) Determination of the drainage structure of a watershed using a digital elevation model and a digital river and lake network. J Hydrol 240(3-4):225-242

Wemple BC, Swanson FJ, Jones JA (2001) Forest roads and geomorphic process interactions, Cascade Range, Oregon. Earth Surf Proc Landf 26(2):191-204

Wemple BC, Clark GE, Ross DS, Rizzo DM (2017) Identifying the spatial pattern and importance of hydro-geomorphic drainage impairments on unpaved roads in the northeastern USA. Earth Surf Proc Landf 42:1652-1665. https://doi.org/10.1002/esp.4113

Publisher's Note Springer Nature remains neutral with regard to jurisdictional claims in published maps and institutional affiliations. 